\title{
British Politics, Economics and Culture in Fascist Discourse
}

We think with pride to our Mussolinian discipline, which out of a people without an empire, without materials and without resources [coming from] old accumulated wealth, made an ordered and tempered nation, where there are not Laburisti, but everyone is a worker. ${ }^{1}$

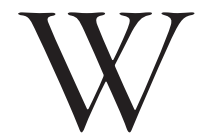

HILE RENZO DE FELICE argued that Mussolini was convinced the corporative experiment was a long-term one, he also maintained that the Duce was sincerely convinced his new system was the way forward in order to avoid the contradictions of liberalism and Communism. ${ }^{2}$ Corporatism was, in theory, a system in which the market and private enterprises were subject to political control and the Fascist regime regulated labour conflicts, serving the greater interests of the nation. ${ }^{3}$ An analysis of Fascist public discourse concerning Britain suggests that, even when the fulfilment of the corporate system was still far in the future, the notion that Fascism had solved the 'problem of labour' was widespread and had implications for the Fascist approach to international relations. Recent historiography has demonstrated the centrality of the idea of labour in Fascist rhetoric. ${ }^{4}$ By 1925 , Mussolini felt confident enough to tell the Italian people that 'Italy did not exhaust itself in creating its first and second civilisation, but is already creating a third.' third was, of course, the Fascist civilisation. Five years later, in the prestigious magazine he edited, meaningfully named Antieuropa, the stern Fascist intellectual Asvero Gravelli predicted the eventual triumph of universal Fascism over both liberalism and socialism, which still dominated much of the European continent. ${ }^{6}$ In 1932, Fascist philosopher Ugo Spirito had written that Fascism sought to export the corporate idea throughout the world. ${ }^{7}$ A change of tone in discussing the corporate system, from national to universal, was evident. The British Ambassador in Rome, Eric Drummond, noticed in November 1933 that Mussolini had come to believe that Fascism was no longer only a national revolution 
but a global one. In fact, he thought that 'in ten years, Europe would be Fascist or Fascistised.' As Claudia Baldoli demonstrated, the contacts between Italian and British Fascists were seen as part of such an initiative. ${ }^{8}$ What were the cultural reasons behind Mussolini's attitude towards Britain in the context of his attempt to create a Fascist Europe? While Baldoli underlined that the attempt to establish a new Fascist European order seemed to develop particularly during the years preceding the Second World War - even though it had been evident from the beginning of the 1930 - the notion that Britain had fallen behind Fascist Italy in terms of political, social and economic development was well ingrained in Fascist public discourse from the mid-1920s, starting with the British general strike of 1926, which represented a major watershed. The Great Depression, without changing this view, radicalised it, so that by the time of the Ethiopian War, it was considered conventional wisdom in Fascist discourse.?

\section{Discourse before the Great Depression}

If British influence over foreign policy was often resented in liberal Italy, the British political model was widely admired. During the decades before the Great War, the debate among Italian politicians focused on whether such a model was applicable in the Italian context, rather than whether things in Britain worked better than in Italy. ${ }^{10}$ This liberal appreciation for Britain lingered throughout the first years of Fascism, with those liberal commentators still active in the country using Britain as an example of freedom of thought and speech. La Stampa - the Turin-based newspaper that was one of the last bastions of the conservative but liberal strand of Italian politics - continued to publish articles in which Britain was lauded as the country of triumphant liberalism, social cooperation and a taste for legality for most of the early 1920s. These articles, in which references to Britain were often used to openly attack growing Fascist authoritarianism, lasted until 1925, when the newspaper was finally 'conquered' by the regime. ${ }^{11}$ Britain therefore represented, in a way, the cultural epitome of liberalism. How did Fascist culture relate to the British 'liberal' example? How did the perception of Britain change during the first fifteen years of the Fascist regime, in relation to domestic affairs, economic doctrines and culture? What had happened so that a country, which was far poorer and rather less developed than Britain, could so optimistically be depicted as solidly on the path of tomorrow, looking with a certain disdain at the British, who still had to 'learn' the lessons of history?

At first, Fascist discourse did not openly attack the British system as an answer to liberal criticism; rather, the British parliamentary system and free press 
were seen as something for which the Italians were simply not ready. At that time, Camillo Pellizzi was an Italian intellectual pursuing an academic career in Britain (he was on his way to become the chair of Italian studies at University College London). He was also a fervent Fascist; he was among the founders of the Italian Fascio of London and contributed to Il Popolo d'Italia, Critica Fascista, Gerarchia and, as Tamara Colacicco underlined, would become the protagonist of Fascist cultural propaganda in Britain. ${ }^{12}$ In 1924, Pellizzi wrote an article entitled 'About English Liberty and Italian License.' The article addressed the incandescent political climate in Italy at the time, as well as the Fascist intimidation of the free press, which was to culminate in the eradication of press freedom within two years. Pellizzi criticised those who, in order to justify their own grievances about the state of press freedom in Italy, appealed to the example of Britain, 'that country so different and far that almost nobody knows.' 'What freedom?' he rhetorically asked the 'zealots of liberty.' As they answered 'liberty in the law,' he proceeded to explain that 'English freedom has no law.' In answering as such, Pellizzi meant that the freedom of speech and press Britain enjoyed was not the product of laws. Instead, the laws were the product of a long historical process, 'an accumulation of many interests and feelings and national instincts of solidarity,' which made these laws, and indeed freedom, possible. In the case of Italy, however,

the deep and naïve instinct of every Italian is universalistic and, only in a second instance, national, the instinct of the English is first of all insular and national, and only after a second moment of reflection and of experience, it can sometimes become universal. ${ }^{13}$

Consequently, the 'first and deepest' instinct of every Englishman was not to harm the moral and material interests of their country - Pellizzi mentioned the well-known motto 'right or wrong, my country [in English in the original].' This, he argued, was the first border and limitation of the proverbial British liberty, given by 'Nature and God' (at the time, Pellizzi was experiencing a religious crisis that would lead him towards Catholicism). Other limitations also existed: the well-defined hierarchy of the classes (whereas in Italy the borders between the classes were, according to Pellizzi, melting), and the various religious sects, all jealous of the other's autonomy. Pellizzi then concluded that Britain was not only liberal, it was 'first and foremost conservative' and always ready to fight for the honour of its traditional institutions: the Crown, the cabinet, the Empire and its various religious sects. All of these were open for discussion in society but were always to be respected. It was this repulsion against the excesses, this 
'discipline of the crew' that allowed the British government to be moderate. Furthermore, the most important limit to English liberty was 'the infinite, jealous respect for the autonomy of individuals, for their rights, sentiments, interests,' amply demonstrated by the harsh sanctions against libel. Pellizzi's conclusion was that English liberty didn't exist in Italy not because of the government but because of the opposition and the lack of general education. If the opposition had wanted to appeal to the English example, it should have demonstrated the uselessness of Mussolini's attacks on the press by behaving responsibly. Lacking that, Pellizzi claimed that the Fascists would help all Italians who liked Britain more than Italy to fulfil their desire and obtain British citizenship. ${ }^{14}$

This feeling soon started to change. After 1925, having finally vanquished domestic opposition, Fascism was attempting to create a coherent ideology. As Renzo De Felice explained, one principle had begun to emerge as the central tenet of the future Fascist doctrine: the replacement of class struggle with something new..$^{15}$ For years, many Fascist intellectuals had been developing a contempt for alleged foreign influence on Italian culture. ${ }^{16}$ What did the Fascists see happening in Britain at that point? While the 1920 s were generally a period of growth for European economies, 1924 saw a relative worsening of economic conditions. This negative economic conjuncture lingered longer in Great Britain than elsewhere. ${ }^{17}$ Occurring just as Italy was beginning to create its corporatist institutions, the general strike of 1926 deeply impressed Fascist commentators, among them Pellizzi. While his article published in Gerarchia in May 1926 still maintained that most British workers had no intention of pursuing revolutionary aims, and that 'social order' was probably going to prevail in Britain, he made it clear that he considered the country a sick one. Britain was, in his words, 'an immense clinic of philosophical, economic and social illnesses in a time of epidemics. ${ }^{18}$ The fundamental problem, he wrote, was that despite the best efforts of the government, Britain was suffering from chaos caused by two apparently opposite forces: 'liberalism and its historical nemesis: the Trade Union.' Compared to two years before, Pellizzi had completely changed his point of view regarding liberalism:

The individual is free and individual property is sacred, and something that is even above the state, for after all the state itself is not composed [of] anything but many single individuals, each with his own sacred real and personal rights. ${ }^{19}$

Hence, workers felt no responsibility not to starve the nation by striking, for 'the right not to work is sacred.' At the same time, 
private property as conceived by the liberal doctrine has no obligation to consider the interests of the nation and the human reasons of the worker. The Trade Union exists in order to ask always more and offer always less. From the struggle between these two egoisms, from the anarchic game of these two opposed, unrestrained interests, nothing can emerge but chaos. ${ }^{20}$

Liberalism had infected society (both British political parties had absorbed the 'anachronistic and false' ideas of the now-dying liberal party) and the government, despite its best efforts, could do very little to solve the crisis. Pellizzi felt that 'here [...] is where Fascism has a reason and right to say its own word. In this fight, the Fascist mentality does not sympathise [with] anyone, for all are mistaken in it.' Whereas the trade unions were pushing for an antieconomic solution and the capitalists were sustaining a 'purely economic' solution, Fascism had solved the 'problem of labour.' The real danger was that this chaos produced a palatable opportunity for the rise of Bolshevism through Soviet interference. While Britain itself was not likely to experience a revolution, its example was dangerous and 'the continent was another matter.' Careful surveillance was needed, and 'Fascist Italy, we are certain, does not sleep on [its] laurels. ${ }^{21}$ The implications of this second piece by Pellizzi were remarkable and all the more astonishing in light of his previous article.

Others shared his feeling that something was rotten in Britain. In March 1926, Virginio Gayda wrote a piece ominously entitled 'The Twilight of Democracies,' in which he divided the world into three blocks. The first, the heir of the past century, was ruled by an inefficient, anachronistic liberalism and unable to face the problems of the new century. The other two groups were the product of a 'protest' against liberalism: Fascism and Communism. Yet whereas Communism - a product of 'barbarous instinct and war weariness' - had only accelerated the destruction of the Russian nation, the 'Roman' values proposed by Fascism were reforming Europe. While it was true that Mussolini had described Fascism as a peculiarly Italian ideology, Gayda wrote, it was a fact that liberal, parliamentary democracy was in crisis everywhere in Europe and Fascism had shown the way to those countries that wanted to reform themselves in a constructive way, looking for safety 'in renounce to the excesses of freedom and individuality.' In Spain, Greece, Poland and even France, the crisis of capitalism and the teachings of the Great War had shown that 'the crisis of democracy, the rise and propagation of Fascism, are not an ephemeral episode, but a new European historical phase [that] corresponds to its new cycle of economic and social transformation and elaboration. ${ }^{22}$ In this picture, Britain was 
no exception. True, its immense wealth and international influence, as well as the typical 'calm and slowness of the Anglo-Saxon race,' made the triumph of Fascism or Communism in the country unlikely. However, Britain was far from an example of a healthy liberal democracy. Despite usually being considered the beacon of liberalism and the parliamentary system, Britain was indeed 'the most conservative and antidemocratic state in Europe,' so that 'it could be said, not being too far from the truth, that it is a feudal state with an exterior democratic appearance. ${ }^{23}$ Furthermore, Fascism and Communism both inspired movements that worked to transform Britain outside of Parliament, a development that was, by British standards, new and astounding. These movements were the trade unions - which detached themselves from the Labour Party and through their strikes experimented with direct action - and the bourgeois class, which organised groups of voluntary workers in case of a strike. The parliamentary tradition that had grown and prospered thanks to previous British economic hegemony over the world, Gayda wrote, was not yet about to be overthrown, but Britain too was changing. ${ }^{24}$ Gayda's article was, even more than Pellizzi's, an obvious endorsement of a new Fascist century, a decade before the Ethiopian War. Britain was depicted as an old, slow, anachronistic pachyderm that represented a backward past. Such was the new philosophy of Fascist intellectuals: Fascism was the philosophy of the future, and liberalism was in decline. In May 1926, Il Corriere della Sera wrote that

the Italians who look at the development of this crisis [. . . ] see in the English situation facts and characters that the Italy of the [postwar] period has sadly experienced [...] The progress made by our country during the last years, compared to European nations, strong and powerful, on the path of disciplined harmony and the willing cooperation of the working forces for the national economic progress, must be acknowledged, once again, and in the clearest way. ${ }^{25}$

In Italy, unlike Britain, May Day had only seen absolute calm and a lack of conflict, as well as the spontaneous rejection by the people of the 'vain ideologies of social subversion.' This clearly showed that, in Italy, the 'order of the souls' reigned. ${ }^{26}$ In August, Giovanni Selvi wrote that Italy did not 'show any symptom of that demo-liberal progressive paralysis that gives Britain the political or economic coal crisis and the inability to produce a vital government to France. ${ }^{.27}$ In May 1927, Gayda expanded his point of view, concluding that Britain was indeed starting to follow the path laid out by Fascism. Describing the new British 
regulation of the trade unions, he claimed that while 'still far from Italian law,' it was the fruit of the 'same political and spiritual environment.' He continued: 'If the problems of the two countries are different in origin and magnitude, they are equivalent and they can be solved in a similar way. By limiting freedom. Because only in that way today can the nation be given freedom to live. ${ }^{28}$ One year later, Gayda was even more persuaded of the weakness of British society and its resultant economic and political decline:

The inferiority of British industry in the competition for world trade has hence also fundamental national causes: insufficiency of technical organization, excessive individualism that rejected the great productive concentrations of the syndicates [...], immaturity of the leaders of industry, despite their glorious tradition. ${ }^{29}$

According to Gayda, British decline was a consequence of the natural law according to which those who stop moving, or prove unable to adapt to the changing world, are destined to 'decadence, in front of foreign rivalries, and then death. ${ }^{30}$

\section{Discourse after the Great Depression}

When the economic crisis hit, Britain was among the countries most severely affected. Although apparently less damaged, Italy was also hit by the economic downturn. Industrial unemployment in Italy was actually worse between 1929 and 1935 than in Britain and, in general, Italy suffered as much as other European countries. ${ }^{31}$ Considering the very different levels of industrialisation of the Italian and British economies, however, the effects appeared less catastrophic. ${ }^{32}$ In this context, the reaction of the Fascist intelligentsia was hardly surprising - the contempt for how things were run in Britain persisted, but for some it became harder to believe they would find the moral strength to follow Italy's example. Furthermore, the birth of Britain's second labour government in 1929 provided more ideological ammunition. Fearful of the panic the British crisis could cause in the Italian financial market, the press was therefore ordered not to 'dramatise' the 'fall of the pound and other grave symptoms of the English crisis.' It was also necessary that 'the financial crisis [was] presented as a consequence of the political crisis, convincing the reader that the crisis can be overcome if other men will be called in the government in England. ${ }^{33}$ If the press had to restrain itself, the intellectual discourse was much more genuine and reveals what Fascists did indeed think at the time. In the midst of the crisis, the journalist Gennaro E. Pistolese blamed the current 
woeful state of the British economy on 'the system of subsidies, which has created the so-called unemployed professionalism and has granted an easier life to [those who] could before only live through their work.' Yet the British crisis was deeper and had even more worrisome causes. One example was the decline of British immigration to the Empire and the Dominions: the problem was not just that the British workforce was too expensive because of concessions to the workers, nor that the demographic crisis was reducing it. The British people, Pistolese wrote, had lost their 'imperial consciousness' and 'pioneer spirit' and preferred to live their comfortable lives in subsidised idleness rather than move to colonies where they would have to work the land. The decline of British agriculture, indeed, was another sign of the decline of British virtues. ${ }^{34}$ This last subject was particularly important for the Fascist regime, with its continuous glorification of rural life and criticism of urbanism. ${ }^{35}$

Another event that helped to convince Fascist commentators that British society was facing irreversible decline was London's departure from the gold standard in September 1931. Giacomo Redentini wrote in Gerarchia that this catastrophic event was symptomatic of an illness that 'corroded the British colossus ... was 'maybe mortal', and for which there was no cure yet in sight. Egoism, Redentini wrote, 'seems to have destroyed the love for risk and adventure in the British race.' He argued that the British people were now hostage to 'the egoism of millions of people who did nothing [nullafacenti],' who cared nothing for the nation's appeals to responsibility and treated with disdain the splendid opportunities for work given by the Empire. Redentini's prose was convoluted, but his message was clear. The 'illness' was likely to cause the fall of the Empire itself. While the Empire was still formidable thanks to its reserves of capital, it appeared to be 'declining because of the lack of these fresh resources, of that moral 'capital' to throw against the overflowing ills, and without that the material resources are nothing but a lifeless reserve of food. ${ }^{36}$

Labour movements, liberalism and 'tired conservatism' had failed to find any solution and 'Britain [did] not show the necessary spontaneous energies necessary to cure the illness.' The fact that the crisis of mercantilism caused such an acute crisis for British political, social and imperial life, Redentini claimed, suggested that it was only mercantilism that gave Britain its raison d'être. The comparison with Italy was harsh for Britain:

Where we see the key of an historical organization is made up by mercantilism, most hard the devastating attack hits, whereas where the vital creating energy starts from the political-social and religious heart of a nation, the resistance $[\ldots]$ is most firm. ${ }^{37}$ 
Writer, explorer and journalist Arnaldo Cipolla - known at the time as the 'Italian Kipling' - agreed that the British people had lost their passion for adventure, that in Britain huge masses of unemployed were idle while the fields lay abandoned and that the corporate system represented the system of the future. ${ }^{38}$ Margherita Sarfatti's son, Amedeo, was less pessimistic. In an article meaningfully entitled 'The Fall of a World,' he wrote that the British people had historically 'always found, in the direst moments, the steel-hard determination necessary to overcome the crisis. ${ }^{39}$ What Britain now had to do was 'ban demagogy of all colours' and drastically reduce standards of living. The example had been given by Fascism, so that Sarfatti wrote that Italians could 'with right and legitimate pride look back to consider the example of solid and foreseeing loyalty given with so many sacrifices by Fascist Italy. ${ }^{20}$ The opinion among Fascist intellectuals was unanimous. Critica Fascista, Giuseppe Bottai's magazine, which was known for its radical, at times anti-capitalist positions, published an article in September by journalist Rodolfo Foà with the same message worded in an even-less-diplomatic manner. According to Foà, 'the British crisis is one of those [that] justif[ies] the state doctrine of Fascism.' The British people knew that something was wrong, but they were still reluctant to turn to Fascism for the solution. No cultured Englishman, Foà thought, would deny in his own heart that

democracy is about to fail even in the classical land [that] gave birth to it. But to ask [...] for something clear to replace the current rusty political machinery would be too much, for in this country, [for] centuries, [society] is used to hear[ing] of democracy, political parties, of the Parliament. ${ }^{41}$

Echoing Pellizzi, Foà remarked that Britain was still the most aristocratic country in the world. British democracy was hence a delusion, but the British temperament meant that the words and forms of this delusion still mattered. Therefore, Fascism was still a scary word for most Britons. However, times were changing. These times were

not [a] fleeting anomaly, but lasting precursors of an era [that] will not have anything to do with the one [that] is now about to wane in a turmoil of things and spirits. It is natural, then, that the English machine, maybe more than any other because of its venerable antiquity, cannot work as before anymore so that the engineers tire themselves in attaching spare parts, and God knows if they will be enough to fix it. ${ }^{42}$

And so if Fascism was still a 'shocking' (in English in the original) word, the whole of British society had now been 'impregnated [for] some months with 
concepts [that] are of the most purely Fascist brand.' Foà maintained that 'people now openly say what they had not the courage but to whisper sotto voce some months ago, that is, that the Democratic regime, party, parliamentary system, they are all nice things, but they have had their time.' He then proceeded to analyse the reasons for the current critical state of the British economy, blaming most of it on the vociferous trade unions. The 'leftist' Fascist Critica Fascista's diagnosis of the causes, the symptoms and the cure of the British disease did not differ from the other commentators. ${ }^{43}$ In addressing the British crisis, Mussolini's newspaper Il Popolo d'Italia used softer tones, without changing the content. On I8 September 1931, it published an article titled 'Young Italy,' which praised the solidity of the Italian social and economic systems. 'We, the article claimed,

that have not great riches or colonies, nor materials nor gold, look with a passion to this wealth [that are our] children, given to the Fatherland by the Italian women, not yet hit still by the decaying and sterile industrial civilization. ${ }^{44}$

The purpose of the article was made clear when, a day later, Il Popolo published 'Old England,' in which the root of the British troubles was summarised: 'the diminishing of the ancient imperial prosperity, [the] indiscipline of the classes and the general difficulty to adapt to the inferior standards [of living] imposed by the crisis.' Britain could only be saved by discipline and sacrifice. Yet even if Britain could emerge from its current crisis, it would still need a 'compact national party and a strong government.' Even beyond the Channel, the war had sterilised the old parties: and the hardened Italians, used to every hardship, were 'following with sympathy' the efforts of the British statesmen to emulate what Mussolini had done. ${ }^{45}$ The comparison between the British problem and the Fascist solution was clear and, disguised under a sympathetic tone, the condescending attitude was palpable.

Camillo Pellizzi returned to the subject of the British crisis in October 1931, and once again his article provides a useful summation of the broader perspective on the subject. The British currency crisis, he argued, had been caused by the decline of nineteenth century society, which rested on two, now quickly eroded, pillars: high standards of living and parliamentary democracy. Both were backed by capitalism, an economic and political force, which made it impossible to heal the wounds of the crisis because of its rejection of authoritarianism (or, in Pellizzi's words, 'the gold which fears the iron'). Once again, the article concluded with a rhetorical question: Would the British people know how to look at Fascist Italy and hence return to their former glory? ${ }^{36}$ Other prominent Fascists tried to answer 
this question: in 1932, Oswald Mosley claimed that Britain was moving towards the introduction of a corporatist system and, in 1934, Hungarian-born Fascist Odon Por wrote that many in Britain felt the country needed a strong government in order to put an end to the citizens' abuse of their rights. ${ }^{47}$ Indeed, Fascist public discourse paid much attention to Mosley's British Fascists in the early 1930 .

As Claudia Baldoli explains, 'in 1933, Fascist universalism considered it a duty to support British Fascists. ${ }^{38}$ As early as June 1931, the journalist Marcello Prati had described Mosley's movement as 'the most alive thing' existing in British politics at the time, and one month later he described Mosley as 'the youngest of the rebels, the denier of normality' who had rebelled against the labour oligarchy and who might well be destined to rule Britain in the future. 'Can you see,' Prati asked the readers, 'the first hints of what happened to politics here? And what could happen [there in the future]?' Still, in 1933, La Stampa wrote with optimism that Mosley's attempt to spread his propaganda through the countryside 'might have [a] decisive effect on the fortunes of his new party'; in the same year, the orders to the press were to give due attention to Mosley interviews. ${ }^{49}$ In 1934 , when a petition against the dangers of a dictatorship in the country was launched by important Britons, the writer and painter Renato Paresce answered in La Stampa by talking of a British democracy that was hopelessly looking for an 'elixir of long life,' remarking how in 'regimes at their sunset' even those opposing dictatorship had to do so by advocating an increase in the powers of the government. ${ }^{50}$ All these articles were perfectly in line with the thoughts of the Fascist leadership. In 1933, Mussolini himself celebrated the demise of the 'demo-liberal' civilisation and its replacement with a new, more vital Fascist civilisation. ${ }^{51}$ An avid reader of newspapers, Mussolini might have been influenced by an article from the conservative National Review, reported in $\mathrm{Il}$ Corriere, stating that liberalism was a spent force and that a Britain that is in a state of doubt, uncertainty and discouragement was waiting for 'The Prince.' Tired of 'the imaginary liberty that brings poverty and slavery' and of a plutocracy in which the wealthy did not answer to anyone, it would gladly accept a strong hand bringing 'order, peace and prosperity. ${ }^{52}$ The Prince was, of course, a veiled reference to Mussolini. The article added that in Italy 'the government is strong enough to rule not only the poor but also the rich, not only the workers unions but also the money, not only the worker but also the capital.' The article concluded with a reference to the growth of the forces of 'order' in Germany in the last elections (March 1933)..$^{53}$

Certainly, Hitler's triumph in Germany had helped consolidate Mussolini's beliefs but, as we have seen, the Fascists had seen themselves as a new beacon 
of civilisation since the earliest years of the regime. From the sparse evidence (especially the orders to the press) available, it seems likely the regime wanted the Italian people to be well aware of the crisis in Britain and of liberalism more broadly, ordering all the newspapers to write about 'the threat of strikes looming on the textile industry in Lancashire' in 1932, and to report Lloyd George's praise for Mussolini and comment on the near end of liberalism in 1933. Soon, Il Corriere wrote that while Lloyd George thought that only then-Soviet leader Joseph Stalin and Mussolini had grasped where the world was going, the Welsh politician had no fondness for the Soviets. Rather, he saw in the Mussolinian conception and implementation of the corporate [system] the state's greatest social reform of the modern era.' His words were, the newspaper commented, an echo of the powerful movement that was spreading throughout Britain, which pressed for the implementation of the corporate system. ${ }^{54}$

By 1934, however, the interest in Mosley's actions, and more generally the hope that Britain would follow Mussolini's path, was declining. Nicola Pascazio's report on British Fascism in 1934 underlined how Austrian dictator Engelbert Dollfuss' bloody repression of the Socialists in Vienna had caused a wave of indignation among the British public to paralyse Mosley's movement. ${ }^{55}$ On 22 January 1934, La Stampa celebrated the enthusiasm raised by Mosley's Fascists in Birmingham, but a day later it had to add with a certain frustration that 'despite the violent moral crisis that shakes it, [Britain] is the only country where the omnipotence of majority is still worshipped today. ${ }^{56}$ The fact that this comment appeared in an article that discussed the 'march of British Fascism,' as well as the crisis of the Conservative Party, is remarkable. ${ }^{57}$ As Pier Filippo Gomez Homen wrote to Ciano, '[the British Union of Fascists (BUF)] had a certain success when the crisis was rampant in England, and with it so was the criticism [of] the parliamentary system, but it loses ground as the economic conditions improve. ${ }^{58}$ Before 1935 Dino Grandi had been optimistic about the growth of British Fascism, telling Mussolini that if Mosley's progress was slow, it was because of the slow pace of social change in British society, which he compared to a tortoise..$^{59}$ By March 1935 he had changed his mind and complained to Mussolini about the funding Mosley was receiving, stating quite clearly that it was a waste of money ${ }^{60}$ From 1935 , the Italian funding of Mosley had started decreasing, diminishing by half in 1936 and becoming negligible by $1937 .{ }^{11}$ However, Mosley, his party and his political influence did not disappear from the radar of Fascist discourse. With the deterioration of Anglo-Italian relations during the second half of the 1930s, a pro-Fascist voice in Britain was duly appreciated. ${ }^{62}$ 
However, by this stage Mussolini had lost faith in his British apprentice's chances of transforming Britain into a Fascist country. There were other reasons for Mussolini's gradual alienation from Mosley, among which was Grandi's belief that the British conservative Italophiles would prove more useful for Italian foreign policy goals than the BUF and the fact that Mosley himself had started looking to Berlin more than to Rome. ${ }^{63}$ Even these factors, however, encouraged Mussolini's conviction that the new Fascist civilisation had to be Roman, Italian and Mediterranean, rather than spontaneously developed by other countries. This development was not limited to Britain and the British Fascists. As Jens Steffek and Francesca Antonini underlined:

the biennium $1935-1936$ represented a crucial watershed in the history of Italian Fascist ideology [...]. Corporativism turned from being seen as the basis of a new and potentially universal economic system to being simply a 'crutch' of Italy's policy of autarky, while the universalistic references closely related to this doctrine now became mere propaganda tools. ${ }^{64}$

The sincerity of the regime's support for corporatist ideas abroad has been debated. However, the firm belief that the Fascist model was superior, and that Britain was doomed to hopeless stagnation by its failure to adopt it, is the consistent message found when analysing Fascist public discourse both before and after the 'crucial biennium' of $1935-1936 .{ }^{65}$

\section{Cultural Discourse: Religion, Masonry, Feminism}

One new, important and little-known strand of criticism towards Britain blossomed vigorously in Fascist discourse in 1935 and remained thereafter - a religious approach. Religion had been important in the thought of many Fascist intellectuals since the early years of Fascism, and with it an anti-Protestant zeal. Curzio Malaparte frequently discussed the need for a Catholic crusade against the modern thought that was a product of the Reformation. Such a mission was justified by the 'separation between us [Italians] and modern, anti-Catholic Europe, created by four centuries of Counter-Reformation. ${ }^{66}$ The importance of the religious theme in Fascism's criticism of its enemies was analysed by Marla Stone, who explored the antisocialist and anti-Soviet discourses over the course of the Fascist movement and regime. Stone concluded that the regime had often resorted to appealing to the Italians' ancestral attachment to Catholicism, which was considered the core of many Italians' system of values. ${ }^{67}$ As for anti-Anglican tropes, these existed in the Fascist press before 1935. In 1933, for example, Il 
Corriere della Sera published an article entitled 'The Anglican Movement in Oxford Fails to Achieve its Goals,' which described how many British believers were returning to the Catholic Church after the attempts to reunite the two churches, known as the 'Movement of Oxford,' had failed. The causes of this massive wave of conversions was a rebellion against 'liberalism in theology and against state control of the ecclesiastic hierarchy. ${ }^{68}$ These preexisting sentiments can be explained with the hopes held by the regime that the Holy See would become an ally of Italy in the Middle East, where Britain controlled the holy sites of Christianity. ${ }^{69}$ Fascist identification of the Italian people with Catholicism, and the growing confidence Fascism had in its universal message and of Italy's role as the beacon of the tomorrow's civilisation, help to explain the favourable light in which many Fascists increasingly saw a Catholicisation of Europe..$^{70}$ At the same time, the notion that the Anglican Church was infected with 'modernism' and 'liberalism' was consistent with Fascist discourse on the decadence of British society, as analysed above. However, a truly hostile campaign against the Anglicans only began with the Ethiopian War and the support given by the Anglican hierarchy to the Ethiopians. From 1936 onwards, countless articles criticising Anglicans for a wide range of reasons (including hypocrisy, greediness, subservience to politics and wealth, as well as their bigotry and liberalism) started to appear in Italian newspapers and magazines. Some of the more thoughtful criticism is, however, due to its coherence with broader Fascist discourse on Britain. ${ }^{71}$

The first volleys were thrown by the fiercely Fascist priest Don Brizio Casciola, who, thanks to his friendship with Margherita Sarfatti, regularly cooperated with Gerarchia through a column on religious subjects. Casciola had a history of reprimands by the ecclesiastical hierarchies regarding his attempts to proselytise among some Italian evangelical communities (the Church's stance was to avoid any contact with Evangelicals). His ecumenical philosophy was often expressed by foreseeing a return of the various Christian sects to the Catholic Church. In this context, his hatred for the 'treacherous' Anglican Church was amplified by the Archbishops of Canterbury and York's condemnation of the Ethiopian War. In a piece published in February 1936, the priest criticised the typical simplistic naivety of Anglo-Saxons when they criticised Mussolini for disturbing world peace. Did they ignore, Cacciola wondered, the fact that the Bible orders men to grow and multiply? According to this principle, the Italians wanted to 'turn deserts into gardens' and that was why they were fighting in Ethiopia. ${ }^{72}$ He then expanded his point into a general criticism of the origins and nature of the Church of England. If the ancient apostles had no mundane interests to defend, the Anglican prelates were mere tools of the interests of the British 
ruling classes. The 'original sin' of the Anglican Church was in its 'rejection of an international religious authority,' so that it now 'depended on the state, which in turn depended on the conservative class.' Furthermore, they had allied themselves with masonry, thereby 'betraying the Christian religion.' The rot had started, in Casciola's view, with the Reformation. Caused by the 'excessive exteriority' of the Catholic Church, it had nevertheless led to an extreme focus on the 'interioritá,' which in turn meant that the Anglican Church had sunk into 'solipsism, anarchy and inhumanity.' 73

The discourse presented the conflict against this treacherous church as a true religious war. Hence, during the Ethiopian War, the press reported on 'Protestant and Anglican elements' actively trying to sabotage the efforts of the Catholic missionaries in Ethiopia, and in the followings years the press gleefully reported of the expulsion from the country of Anglican missionaries, which it claimed were spies and saboteurs. ${ }^{74}$ Il Giornale d'Italia attacked the Anglican missions in general, writing that they were 'creating spiritual disorder' and undermining Italian authority: 'That is the case with the British missionaries, and their brothers, who followed their impure path. ${ }^{75}$

Like many other facets of the Fascist criticism of Britain, the religious one found at least some important supporters in Britain itself. Mussolini's settlement of the long dispute between the Italian state and the Vatican deeply impressed many British Catholics. ${ }^{76}$ As a consequence, many important British Catholics supported Mussolini's actions in Ethiopia and had strong Fascist sympathies. ${ }^{77}$ Their works were often quoted by the Fascists, especially during the Second World War. In 1937, British polemist and historian Hillaire Belloc wrote a booklet titled The Character of Contemporary England, which included strong criticism of the Anglican Church. The piece was promptly published in Italy that same year and was later quoted in La Difesa della Razza in 1943. According to Belloc, the British hatred of Rome had strong religious connotations and was mixed with the traditional sense of racial superiority held by all Englishmen:

Today [...] the fundamental feeling of hostility against Rome and all the European Catholic culture is as strong as before. The Catholic Church is still an extraneous institution for [the Church of England] and their followers [...] It is an hateful institution because it is foreign. ${ }^{78}$

Belloc's thesis was often repeated by the Fascist press. In 1942, writing about the ongoing British debate over whether to separate the Anglican Church and the State, an article in La Stampa depicted the discussion as an anti-Catholic move driven by the secular tradition of hostility and envy the Anglicans held for 
Catholicism. 'Churchill's England is substantially as anti-Roman and anti-Papal as the England of Henry the VIII,' the article wrote. ${ }^{79}$

Alfredo Obertello - professor of Italian literature at the University of Cardiff before the Second World War - described the British idea of religion (regardless of denominations, which he defined as 'squabbling factions') as a merry form of atheism, 'for it had lost the permanent absolute value, the divine law, a comfortable human connivance. ${ }^{90}$ Since British culture conceived of life as a ruthless struggle for success and wealth, in Britain, religion was acceptable only as long as its positive rules were not a burden or a hindrance to the pursuit of material achievements. In the second half of the 1930s, the Anglican Church became one of the favourite targets of attacks by the newspapers, which focused on its supposed arrogance, hypocrisy and growing ties with Bolshevism. ${ }^{81}$ The British sense of superiority was explained by Curzio Villa using religious reasons. ${ }^{82}$ The accusation of solidarity with Bolshevism peaked with the Second World War and the Anglo-Soviet alliance in 194I. The Italian press could then write that 'the Anglican Church, for an abhorrent solidarity with the enemies of the Axis, has become the paladin of Bolshevism, getting to this paradoxical sacrilege of asking God to bless and protect the ones who deny him. ${ }^{83}$ The Anglicans also horrified Fascist commentators for other reasons. Their support for birth control was both deeply anti-Catholic and inconceivable for a regime that considered demographic decline as the symbol of the death of a people. As one Fascist commentator put it, the Anglicans, who favoured the reduction in births and supported Bolshevism, had one goal: to fight Fascism. ${ }^{84}$

With the introduction of state anti-Semitism in Italy from 1938 onwards, this line of thought gradually led to the association of Anglicanism with Judaism. The accusations made against one religion were similar to ones made against the other. The association between the two groups led to anti-Axis demonstrations in Britain 'with the participation of high rank prelates, indiscriminately flanked by rabbis or other directors of the Jewish communities or by representors of the Third International. ${ }^{35}$ Celine's words about Protestantism being a Jewish creation were reported in $\mathrm{Il}$ Corriere. ${ }^{86}$ During the Second World War, the fiercest anti-Semites started to explain this cooperation as based upon an innate connection between the British and Jewish concepts of religion. According to Gino Sottochiesa, British Puritanism (which he seemed to associate with Anglicanism) was quintessentially British and Judaic at the same time. Its 'pretences of self-election and world dominance' were similar to that of the Jews, and granted the Briton a sort of divine right over the world, a 'new Jehovah transplanted from Jerusalem to London. ${ }^{87}$ 
In the same way, according to Sottochiesa, the general Puritan cruelty, hatred and close-mindedness was reminiscent of the harshness of the Old Testament. Whereas National Socialists often praised Oliver Cromwell, even comparing him to Hitler, the article described Puritan England under Cromwell as a country where 'a dark sadness surrounded all things,' with a flood of Jews invited by Cromwell and to whom the 'dictator' granted many privileges ${ }^{88}$ Cromwell's England looked to the Jewish Old Testament for hints that the British themselves were the Chosen People; such a belief had survived until the twentieth century within the notion that 'the current English rulers, who monopolised the essence and will of God,' were waging war against the Axis as a crusade under the banner of the English God. After all, it was not surprising, Sottochiesa argued, that many Britons claimed that the English and the Jewish peoples were one. 'Anglo-Hebraism,' the article concluded, forged by Puritan praxis, was now part of the British nature and could not be erased. ${ }^{89}$ The Jewish influence in Britain was explained by another author as the result of a decline in Catholicism in the country. The Catholic Kings had banned the Jews, and the Puritan Cromwell had allowed them to come back. The 'Anglo-Judaic' affinity dated back to that fateful day and had developed to the point that

the English are the only European people who do not just reject, but even invent the story of its lineage from the Chosen People, even believing to have demonstrated that the English are one of the ten tribes lost after the destruction of Jerusalem. ${ }^{90}$

The Jews, for their part, also had great sympathy for the British. While economic interest contributed to this entente (London had supposedly become the centre of Jewish trade), the true reason was 'the similarity between Christianity as the English conceive it and the Hebraic religion.' Both were 'capitalistic religions' that saw God's grace in wealth alone, which justified Jewish and British harshness against the poor. Both were based on the idea of being the Chosen People, 'which provided both the English and the Jews with a divine justification for any violence or trick acted upon other peoples. ${ }^{\prime 91}$ Many other articles in La Difes $a$ and elsewhere stressed the link between the two religions. ${ }^{92}$

The anti-Anglican discourse was partly shaped by foreign policy, a desire to uphold 'Italian-ness' and hence Catholicism, and eventually anti-Semitism. Fascism represented the Anglican Church as a form of religious anarchy, 'modern' in an unacceptable way, and at the same time grimly Puritan, both materialistic and hopelessly anachronistic, and definitely incompatible with Roman, Catholic and Fascist ecumenical aspirations. 


\section{Critique of British Feminism}

Fascist scholar Guido Manacorda described masonry as a 'pseudo-religion' with clear ties to Judaism and Anglicanism..$^{93}$ The Scottish Rite Masonry was of 'very obvious English brand,' with occasional 'dangerous incursions in[to] the blackest Satanism. But these things happen, usually, to Puritans. ${ }^{94}$ All these sects, according to Manacorda, had developed the same demo-Anglo-Saxon cultural features and thrived in the old, rusty and withered societies of the West. Like its French and American 'sisters,' it rested on a mediocre philosophy: the rejection of metaphysics, individualism, empiricism and hedonism, which in turn meant 'license, whims, pleasure.' Masonry also meant the destruction of the family and the spread of feminism. ${ }^{95}$ As Patrizia Dogliani underlined, Fascist policies concerning women presented a glaring contradiction. The regime successfully strove to Fascistise a vast number of women in the north and the centre of Italy through its nontraditional models of femininity (like sports, culture and other forms of participation in public life). However, it also expected them to remain within the closed doors of their home and family after marriage, virtually disappearing from public life, with the exception of the ritual appearances required by forced mobilisations during Fascist demonstrations. Women were therefore necessarily going to submit to their husband..$^{96}$ Western feminism was seen by many in the Fascist elite as caused by the decadence of masculine supremacy and strength in Britain. It was also considered a sign that women rejected their rightful place in society. Rather than violently attacking feminism, however, Fascist commentators resorted to ridicule. In 1938, one article in Il Corriere laughed at the prospect of a 'female army' being organised for the defence of Britain; the author finding the notion of aspiring generalesse particularly amusing. ${ }^{97}$ Another article from the same newspaper, drafted in 1939 , described the terrible conditions of 'the so-called Strong Sex' in Britain, where female workers mistreated their male colleagues to the point that the latter had been forced to organise a league to protect men. ${ }^{98}$ In September 1941, journalist and writer Paolo Monelli - who was to remain an important intellectual after the war - claimed that British women were not simply equal to men in all aspects of society, including sexual morals, but actually enjoyed a privileged position over men. It was from this 'confusion of roles' that much of Britain's weakness stemmed. Another journalist wrote in Il Mattino that British womens' psyches were 'abnormal,' as their dubious, familiar morality showed..$^{99}$ In 1943, a correspondent identifying himself only as 'Minosse' wrote in Il Corriere that the most harmful effect resulting from the participation of women in the industrial sector because of the war was that it undermined the moral basis of society. According to 'Minosse,' 
unlike in the well-organised totalitarian countries, where 'women are tasked with duties fitting their familiar and social function,' in Britain, women, who were very spoiled even before the war, now felt completely independent and equal to men. The catastrophic effect, the author thought, was that the demographic decline could be attributed to 'the firm principle of the English women not to give up their independence. ${ }^{\prime 100}$ In general, it was clear that Fascist discourse was viscerally offended by the perceived role of a 'liberated' woman existing in British society. Still, on 21 April 1945, a few days before the end of the Fascist regime, La Stampa reported that 7000 English girls between $\mathrm{I} 3$ and 17 years old had been arrested for crimes against public morals. This was proof that, while the British acted as defenders and teachers of moral order, they were clearly inferior in both to the Italian people, whose girls did not give such problems. The article also connected 'English liberty, and its moral degeneration, with the misery of British lower classes. ${ }^{101}$

In Nazi Germany, once relations with Britain had definitely soured, the regime depicted it as an 'old' country. As we have seen, the same happened in Fascist Italy. In Germany, however, German technological supremacy and alleged British technological backwardness were fundamental parts of the discourse. ${ }^{102}$ Consistent with the futurist aesthetics of Fascism, images of a thundering, lethal Fascist war machine vastly ahead of a desperately clumsy and slow British behemoth can be found in Fascist military discourse. ${ }^{103}$ Defeats at the hands of the British during the Second World War surprised many, for the notion of a technologically advanced Britain fighting a tragically unprepared Italy was far from widespread when Mussolini decided to join the Second World War (see chapter 3). At the same time, the emphasis on the youthful nature of the Italian people and the Fascist revolution meant that the comparison with the elderly, sterile Britain was unavoidable. This 'old versus new' trope was how the rivalry between Britain and Italy was often explained. However, the overall technological disparity between Britain and Italy meant that while the decrepit nature of British society was one of the most popular tropes, it did not automatically translate, like in Germany, in the idea of a materially backward Britain. Mussolini was, after all, keen to underline that it was spirit, and not matter, that moved history.

\section{Cultural Discourse: British Character and Art}

British culture was at times used as an example of what was wrong with British society. One enlightening example was Mario Praz's commentary on the $1935 \mathrm{mu}-$ sical version of the satire 1066 and All That. Praz was one of the few Italian Anglisti (he would create the first school for English studies in Italy) and was one of the 
country's leading experts in English literature. He was also a fervent Fascist who would later collaborate with Bottai's magazine Primato. ${ }^{104} \mathrm{His}$ understanding of Britain did not shield him from interpreting the culture of the country with a truly Fascist attitude. Praz commented that 'in England the most depressing spectacle is not the unemployment of the youth but the golden, bored and valetudinarian comfort of too many old men. ${ }^{105}$ Theatre itself looked like an old, second-rate cinema, squalid and suffocating: such was the context in which 1066 and All That was represented. The nonsensical nature of the play was, Praz admitted, part of a venerable British tradition. Yet what surprised Praz was that the targets of the play were not 'the Gods of Homer or the politicians of the time or the happenings of the year.' It was instead 'the venerable characters of the national history [that] danced in a grotesque ballet, and the most appreciated songs are nothing but that humorous version of the popular songs of the war.' Praz's surprise was understandable. The Fascist regime's grip on culture, with all the importance it gave to presenting Italian history as a logical development towards Fascism, as well as with its sacralisation of the Great War, made pieces like 1066 and All That unlikely to appear in Italy. ${ }^{106}$ With 1066 ignored, Praz wrote, whether it could be said that the British people were so comfortable and crystallised in their status quo that they could detach themselves from their own history and smile about it, like someone who had reached the top of a tower and looks at 'the silky ladder [that] helped him to reach it.' He knew, however, that for other people, 'past history is still lived and suffered as a present destiny, not detached parody. These peoples did not sit on armchairs, the streets of their cities are not afflicted by the golden, bored and valetudinarian comfort of too many old men. ${ }^{107}$

More sophisticated was the anti-British satire of Fascist writer Curzio Malaparte. Malaparte had a controversial relationship with the regime; an ardent intellectual supporter of Mussolini during the 1920s, he was stripped of his party membership in 1933, was arrested and forced to the confino for years. He was a journalist during the Second World War, after the end of the conflict moving towards Communist and Catholic positions, before eventually becoming a Maoist. More consistent was his hostility towards the Western powers. Between 1933 and 1934, Malaparte published many articles in Il Corriere della Sera (a collection of these would eventually be published in 1960 as L'Inglese in Paradiso), Malaparte ironically described the English character as other from the rest of the European people. ${ }^{108}$ The English, Malaparte wrote, were like angels:

I love the English, their shyness, their haughty diffidence, their smiling contempt, the candor of their foreheads covered with light freckles [...] 
Alas, I love the English, and my feeling for this cold and quiet people, with its red lips, their white and soft hands, is not that different from that which makes one bow in front of the images of angels, martyrs and saints. In front of the English, as if in front of a holy icon, I feel human. ${ }^{109}$

As 'all is allowed to the English, all is forgiven to them before in advance. No good deed manages to darken their conscience. No sin damages them. ${ }^{\prime 10}$ This ironic label was the result of the English peoples' unshakable sense of superiority and trust in its own manifest destiny. While it has been claimed that Malaparte's essays were sympathetic to the British under the veil of irony, the picture of the English people emerging from Malaparte's words is hardly positive. ${ }^{111} \mathrm{He}$ attacked many of what he perceived to be the flaws of English character, from their love for and identification with animals ('for an Englishman there are but two really and supremely civil peoples: the English and the animals), their peculiar understanding of Greek classicism to their attitude towards any other people ('the Children of Albion, lucky them, do not love anyone but themselves. They do not care about the others, or despise them, or sneer at them or, what is worse, take them under their uninterested and unsatiable protection'). All were, in turn, the object of Malaparte's irony. ${ }^{112}$ Malaparte's sympathy for Britain had certainly disappeared for good by the time he wrote some vicious anti-Greek and anti-British articles during the Second World War. ${ }^{13}$

Denis Mack Smith asserted that British literature was used as proof of the decadence, unmanliness, materialism and godlessness of England. ${ }^{114}$ However, in fact, British culture was not always criticised. Just as the prestige of Italian intellectuals and professors had been consistently used to promote the image of Fascism and of Italy, the Fascists tried to use the appeal Italy always had for British intellectuals, or these intellectuals' criticism of Britain, in order to achieve the same goals. ${ }^{115}$ One famous example is George Bernard Shaw. The Irish-born playwright and polemicist was known for his criticism of British society and politics, and was hence 'enlisted' as a tool of anti-British Nazi discourse, to the point that Nazi Minister of Propaganda Joseph Goebbels claimed that, without him, his domestic propaganda would have been considerably weaker. ${ }^{116}$ Perhaps British culture was not well known enough in Italy for Shaw or other writers to be considered essential to Fascist discourse. ${ }^{117}$ Shaw - a personal admirer of Mussolini - was, however, referred to when it was deemed useful to use a British source to attack Britain. In 1930, Shaw's words castigating the vices of universal suffrage and democracy were printed in Il Corriere. His attacks against British foreign policy and the League of Nations were reported, and when in 1938 Shaw 
reprimanded those who dared to call Mussolini and Hitler dictators, explaining that Fascism was instead 'a new form of government,' he was praised in the newspapers as a great antiparliamentary author. ${ }^{118}$ Furthermore, he was considered of enough importance, together with Shakespeare, to be one of only two playwrights from 'sanctionist' countries who was not banned from Italian theatres during the Ethiopian War. Likewise, his plays were not removed from theatres even during the years of the Second World War. ${ }^{119}$ Shaw was not alone in being willingly represented as part of a 'good Britain.' In 1937, commenting on an homage given to Mussolini by a group of British writers, Il Corriere commented that this demonstrated that not all British people were against Fascism and Italy:

[This episode] confirms how the feeling of the English people regarding Italy is represented not only by the labour deputies and by the respective if not respectable deputatesse, nor by the archbishops of the various denominations, nor by the intelligence service, nor by the papers financed by the producers of cotton and weapons. Another England exists, numerically smaller and [that] counts little in electoral games, but [that] must account for something in the struggle of ideas. ${ }^{120}$

The fact that this sample of the British people were small did not matter, for Fascism denied the 'democratic mind-set' according to which it was the numbers that mattered. The article went on to praise Mussolini's proclamation of the importance of poetry in the modern, mechanic world; but, what is interesting here is that far from condemning British culture, in this case it was praised as the only healthy aspect of the British people. ${ }^{121}$ However, the British university system was described as a nest of anti-Fascists, young dandies blinded by Jewish lies about Fascism and seduced by Bolshevism. The Fascist journalist Pietro Carbonelli wrote an article about the 'extremists with an Oxfordian accent.' Carbonelli's piece is particularly interesting, for it manages to combine Fascist hostility for the supposedly degenerate, weak and snobbish elite with the growing belief that British culture was by then in Communist hands. In Carbonelli's words,

it is a fact understood even by the English that among the highbrows [in English in the text] of the upcoming generations and especially among the youth of the universities, not few are the ones who [...] think they are marching towards the future getting a card of the University Labour Federation and mumbling the anti-Fascist litanies of model professors. ${ }^{122}$

One simply had to go to any British university to 'meet everywhere these Bolsheviks with a feminine skin' celebrating the Soviet revolution or collecting 
funds to help the Reds in the Spanish Civil War. Fifty years ago, Carbonelli reflected, the Oxford-accented British youth spoke a very different language, inspiring themselves with the works of Kipling and Cecil Rhodes. ${ }^{123}$ The resolution voted for by some students, which said that they would not fight for King and Country, would have been inconceivable then. Yet at the time, Carbonelli wrote the following:

Today, instead, Professor Laski, internationalist Jew with one foot in Moscow and one in New York, is considered 'the most genuine exponent of the new British intellectuality.' The toxins of extremism spread from the university halls to the village schools, polluting the spirit of the nation and seeding hatred and resentment against other countries. ${ }^{124}$

Jewish influence was not the only reason for the supposed sorry state of British youth; once again, a British intellectual with Fascist sympathies was mentioned in order to give strength to the argument. Carbonelli quoted the British author, playwright, journalist and composer Beverley Nichols, stating that Britain was a 'nation without a hero.' Nichols himself had met Oswald Mosley in 1937 and was convinced that he was the hero Britain needed. ${ }^{125}$ Nichols' assessment, Carbonelli thought, was a

terrible diagnosis, that alas needs no counter-analysis to be accepted. In the greyness of a decaying democracy the British youth, without a hero, was caught by discouragement, and was overrun by Muscovite nihilism, dazzled by Judaic messianismo [. . .] so that the students of Oxford and Bloomsbury read Challenge or New Commonwealth, drying their aristocratic lips with adorned napkins around tea tables, profess their anti-Fascism nibbling pastries, and repeat by memory words by Marx and Engels, [drinking] at ten a.m. a diabolic cocktail based on gin and advokaat. ${ }^{126}$

Carbonelli's analysis makes it clear that, despite the few 'good' educated Englishmen who supported Fascism, British education and culture were, if anything, corrupting forces for the spirit of the nation.

Unsurprisingly, the criticism of British culture peaked with the Second World War. The assumption was that, under the apocalyptic firestorms that were engulfing Britain, the British people, unwilling to renounce their entertainments - theatre in particular - were losing their restraints, enjoying despicable pleasures while the world around them was collapsing. The government, instead of trying to limit these excesses, supported them in order to show the world that British theatre was far from dead, even under the bombings. Scantily dressed women, alcohol and partying therefore helped Londoners to forget the war they 
were losing. ${ }^{127}$ Oxford was but a shadow of its former self, 'flooding with refugees'; where once the 'language of Shakespeare was spoken [now] the accents of Eastern European Ghettoes are heard.' ${ }^{\text {'28 }}$

\section{A Fascist Future}

Long before the Great Depression, Fascist intellectuals saw the British political, economic and social system as a relic of the past, unable to keep pace with the new, increasingly Fascist world. The reason Fascists devoted so much energy to criticising a still-friendly country is that they were responding to and appropriating a narrative that existed in Britain itself. As Richard Overy explained,

the conditions of the British economic crisis in the 1920s, brought briefly to a head with the General Strike of 1926 and the short downturn in the business cycle that year, made the argument for [economic] decadence plausible, and it is significant that the idea of decline was widely embedded in public discussion of the economy well before the onset of the economic crash of $1929-1932$ lent overwhelming historical weight to the argument. ${ }^{129}$

The British mind-set sheds light on the Italian Fascist one. Fascist commentators certainly observed the British crisis with what we could describe as confirmation bias, but Fascist discourse was not merely propaganda destined for internal consumption. The 'constant theme of civilization in crisis' spreading in British society and culture during the interwar years was mirrored in Fascist discourse, while certainly distorted by the interests of the regime and the cultural biases of Fascist commentators. ${ }^{130}$ As underlined by Emilio Gentile, Fascism was conceived as a positive ideology in the sense that it was more than an antiliberal or anti-Communist doctrine, as well as one that proposed a transformation of society according to its own principles. Such a project, Gentile argues, proved popular outside Italy. ${ }^{131}$ As Matteo Pasetti wrote,

Indeed, of the watchwords of Italian Fascism, corporatism was one that from the outset attracted considerable attention abroad. In the early years of Mussolini's government, some Fascist proclamations, including those addressing the end of class struggle, the integration of organised interests in the state and the need for a new political representation as an alternative to liberal democracy, crossed national borders. ${ }^{132}$

This does not mean that efforts to sell corporatism as the way forward succeeded. In fact, as we have seen in the British case, in particular, Mosley's Fascists remained a minor force in the political landscape. Yet just as many abroad 
considered Fascism the recipe to heal the ills of modernity, and therefore sometimes looked to Italy with a different attitude than in the past, in the same way the Fascists compared what was going on in Italy and in Britain and began to nurture a series of convictions and prejudices that proved of enduring importance. Observing what was happening in Britain, Fascist commentators were drawn to make comparisons with how they had (in their view) saved Italy from the economic and social troubles of the postwar era. They saw the Fascist model as the cure for these ills. From a grudging admiration, which, in the early 1920 s pictured British society as mature enough for freedom compared with an Italian people needful of a strong educator, Britain rapidly became, in the eyes of many Fascists, the country of old men and plutocrats, of the 'full belly rights' and of endless strikes. By 1930, such a view was held by the most important Fascist commentators. Even more, this idea of Britain helped the Fascists to frame Fascism itself as a universal movement, the only 'right' way to face modernity and eventually as a message of salvation for the whole world. In this sense, the framing of Britain as an anachronistic, undisciplined society was more necessary to the domestic needs of the Fascist commentators than to their foreign policy programs - it was 'the other' needed in many a religion, political or otherwise.

The Great Depression did not radically modify this narrative. During this first phase, a relatively nonconflictual attitude prevailed - the idea that Britain was eventually bound to become Fascist. Rather than the Great Depression, what changed things was the eventual realisation that Britain was not likely to convert to Mussolini's new civilisation, or at least not by itself. The Great Depression's contribution was not to persuade Mussolini of British weakness (even if it undoubtedly reinforced his belief that it was so), but it rather made the Duce's hegemonic goals appear more realistic, first with and later without need of a Fascist revolution elsewhere (see the previous chapter). Eventually, knowing that he could not conquer the world with the force of ideas, Mussolini decided to adopt a more confrontational attitude towards Britain, starting a political shift that eventually led to his downfall. A more conflictual attitude ensued: the Duce challenged British opposition in Ethiopia and started a march towards controlling the Mediterranean, which culminated in his intervention in the Second World War. In terms of public discourse, after the beginning of the Ethiopian War the focus of Fascist criticism shifted to British foreign policy, as the previous chapter has shown. However, the discourse never completely stopped criticising British society or its political system. ${ }^{133}$ The bitter state of relations with Britain meant that hinting British society was following the path traced by Fascism was problematic at the very least. The academic and politician Pietro Chimenti 
seemingly solved the problem by writing in Gerarchia that, while the British Parliament and Church did not miss any chance to attack Fascism, Britain was nevertheless ruled, de facto, by ministerial decrees, hence demonstrating a decline in British democracy. The Fascist system, of course, worked better than such a hybrid system because it was based on cooperation. ${ }^{134}$

Renzo De Felice wrote that, in the 1930s, and especially after the Ethiopian War, Mussolini believed he was the answer to the degenerative sickness that (as Oswald Spengler had confirmed for him) was afflicting the West, finding a third way between Communism and capitalism. As MacGregor Knox noted, this was not a new theme, as Mussolini had believed in the need to bring down the current status quo and create a new civilisation since his socialist years. ${ }^{135}$ However, Mussolini's beliefs had not been dormant between his conversion to nationalism and the 'awakening' of the aggressive, 'universal' Fascism of the r930s. Instead, they had informed much of Italian public discourse since the Fascists had managed to monopolise it. Furthermore, far from being caused only by Mussolini's personal idiosyncrasies, such a mind-set had been brought about by a combination of the peculiar ideological ethos of the Fascist movement and regime with the witnessing of the crisis that Britain was going through during the 1920 .

In the second half of the 1930 , criticism of British domestic life expanded beyond economic and social matters to encompass religion and culture. Mussolini did not simply hope to cooperate with the Vatican to expand Italian influence in the Middle East, the Mediterranean and the Danubian-Balkan area; he also hoped that the Vatican itself would side with Rome against the Protestant power that controlled the Holy Sites. ${ }^{136}$ Gradually, Catholic attitudes mixed with the new anti-Semitic urges of the regime and produced a violent anti-Anglican discourse that had not been present before. Concerning culture, it is hard to find traces of a Fascist analogue of the Nazi discourse about the 'land without music.' There was instead a mixed attitude, suspended between criticism for a supposedly decadent and certainly 'unfascist' world of culture and praise for those British intellectuals who embraced Mussolini and Fascism. 